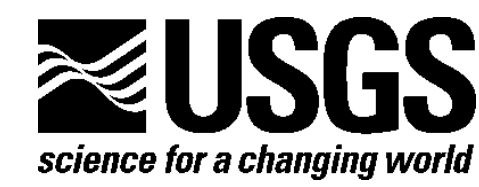

In Cooperation with the Louisiana Department of Natural Resources

\title{
Accuracy of EAARL Lidar Ground Elevations Using a Bare-Earth Algorithm in Marsh and Beach Grasses on the Chandeleur Islands, Louisiana
}

By Kara J. Doran, Asbury H. Sallenger, Billy. J. Reynolds, and C. Wayne Wright

Open-File Report 2010-1163

U.S. Department of the Interior

U.S. Geological Survey 


\section{U.S. Department of the Interior \\ KEN SALAZAR, Secretary}

\section{U.S. Geological Survey \\ Marcia K. McNutt, Director}

U.S. Geological Survey, Reston, Virginia 2010

For product and ordering information:

World Wide Web: http://www.usgs.gov/pubprod

Telephone: 1-888-ASK-USGS

For more information on the USGS—-the Federal source for science about the Earth,

its natural and living resources, natural hazards, and the environment:

World Wide Web: http://www.usgs.gov

Telephone: 1-888-ASK-USGS

Suggested citation:

Doran, K.J., Sallenger, A.H, Reynolds, B.J., and Wright, C.W., 2010, Accuracy of EAARL lidar ground elevations using a bare-earth algorithm in marsh and beach grasses on the Chandeleur Islands, Louisiana: U.S Geological Survey Open-File Report, 2010-1163, 9 p.

Any use of trade, product, or firm names is for descriptive purposes only and does not imply endorsement by the U.S. Government.

Although this report is in the public domain, permission must be secured from the individual copyright owners to reproduce any copyrighted material contained within this report. 


\section{Contents}

Introduction

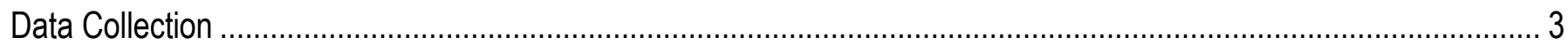

Analysis

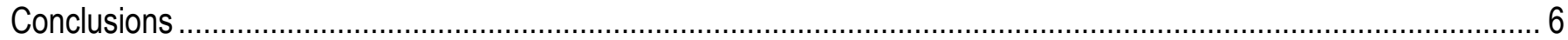

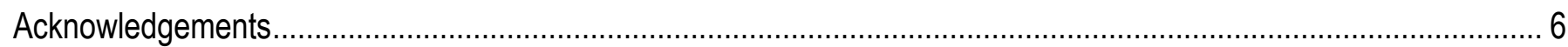

References Cited

\section{Figures}

Figure 1. Map of the Chandeleur Islands showing the survey location. ............................................................ 2

Figure 2. First-return lidar elevations compared to the nearest bare-earth elevations within the survey area............. 4

Figure 3. Bare-earth average lidar elevations compared to ground-survey elevations......................................... 5

Figure 4. First-return average lidar elevations compared to ground plus vegetation height survey elevations. ...........5

Figure 5. Photographs taken of the survey area showing vegetation types. ...................................................... 7

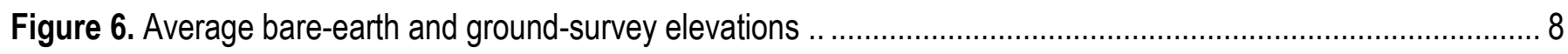

Figure 7. Average first-return elevations and ground-survey elevation plus vegetation heights............................. 9 


\section{Conversion Factors}

SI to Inch/Pound

\begin{tabular}{|c|c|c|}
\hline Multiply & By & To obtain \\
\hline \multicolumn{3}{|c|}{ Length } \\
\hline meter $(\mathrm{m})$ & 3.281 & foot $(\mathrm{ft})$ \\
\hline kilometer (km) & 0.6214 & mile (mi) \\
\hline kilometer $(\mathrm{km})$ & 0.5400 & mile, nautical (nmi) \\
\hline meter (m) & 1.094 & yard (yd) \\
\hline \multicolumn{3}{|c|}{ Area } \\
\hline square meter $\left(\mathrm{m}^{2}\right)$ & 0.0002471 & acre \\
\hline square meter $\left(\mathrm{m}^{2}\right)$ & 10.76 & square foot $\left(\mathrm{ft}^{2}\right)$ \\
\hline
\end{tabular}

Vertical coordinate information is referenced to the North American Vertical Datum of 1988 (NAVD 88). Horizontal coordinate information is referenced to the North American Datum of 1983 (NAD 83).

Elevation, as used in this report, refers to distance above the vertical datum. 


\title{
Accuracy of EAARL Lidar Ground Elevations Using a Bare-Earth Algorithm in Marsh and Beach Grasses on the Chandeleur Islands, Louisiana
}

\author{
By Kara J. Doran, Asbury H. Sallenger, B. J. Reynolds, and C. Wayne Wright
}

\section{Introduction}

The NASA Experimental Advanced Airborne Lidar (EAARL) is an airborne lidar (light detection and ranging) instrument designed to map coastal topography and bathymetry. The EAARL system has the capability to capture each laser-pulse return over a large signal range and can digitize the full waveform of the backscattered energy. Because of this ability to capture the full waveform, the EAARL system can map features such as coral reefs, beaches, coastal vegetation, and trees, where extreme variations in the laser backscatter are caused by different physical and optical characteristics. Post-processing of the EAARL data is accomplished using the Airborne Lidar Processing System (ALPS) (Nayegandhi and others, 2009). In ALPS, the waveform of the lidar is analyzed and split into first and last returns. The "first returns" are indicative of vegetation-canopy height, or bare ground in the absence of vegetation, whereas "last returns" typically represent "bare-earth" elevations under vegetation.

To test the accuracy of the first-return and bare-earth EAARL data, topographic and vegetation height surveys were conducted in the Chandeleur Islands, concurrent with an EAARL lidar survey and an aerial oblique-photographic survey from September 20 to 27, 2006. The Chandeleur Islands are a north-south-oriented chain of low-lying islands located approximately 100 kilometers $(\mathrm{km})$ east of the city of New Orleans, Louisiana (fig. 1). The islands are narrow north-south strips of land with marsh on the landward (west sides) and sandy beaches on their gulfward (east sides). Prior to Hurricane Katrina, which made landfall at Buras, Louisiana as a Category 3 storm on August 29, 2005, prominent, 3- to 4meter (m)-high sand dunes were present in the northern Chandeleurs. The storm removed them, leaving post-storm island elevations of generally less than $2 \mathrm{~m}$ above 0.0 NAVD88.

This report is part of a study of the impact of Hurricane Katrina on the Chandeleur Islands using pre-storm and post-storm lidar surveys to detect morphological changes. The islands lost over 80 percent of their land area during Hurricane Katrina, and in the first 2 years following Katrina, many of the islands experienced continued shoreline retreat (Sallenger and others, 2007). In addition to land-area losses, the loss of dunes made the islands increasingly vulnerable to future storm impacts. The U.S. Geological Survey (USGS), along with partners in the Louisiana Department of Natural Resources and the U.S. Army Corps of Engineers, continues to monitor changes in shoreline position, land area, and elevation in the Chandeleur Islands. 


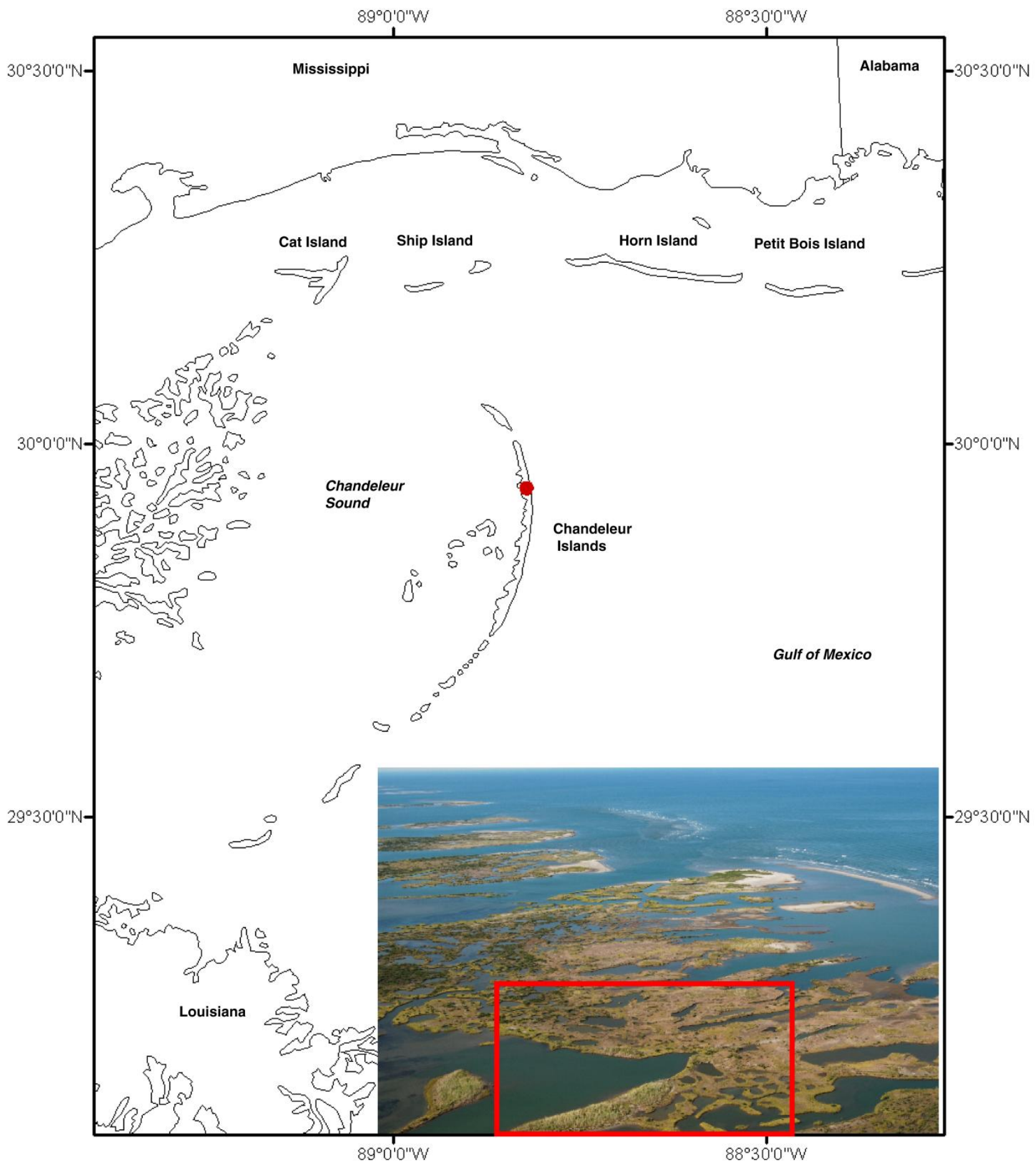

Figure 1. Map of the Chandeleur Islands showing the survey location (red dot). The inset photograph is an enlargement of the general location at the survey location taken on September 26, 2006, during an oblique aerial- photography survey. Approximate extent of the local topographic survey is outlined by the red box. 


\section{Data Collection}

An EAARL survey over the Chandeleur Islands was conducted on September 20 and 21, 2006, as part of continued monitoring of the area since the impact of Hurricane Katrina. The area was covered by multiple overlapping passes to ensure complete coverage of the islands. Typical EAARL flights

survey a swath width of $240 \mathrm{~m}$ and provide one laser pulse every 2 to 4 square meters $\left(\mathrm{m}^{2}\right)$ (Nayegandhi and others, 2006). The lidar survey acquired full waveforms that were then processed in ALPS to acquire both first-return and bare-Earth elevations. The lidar first and last returns are the first and last backscatter to return to the sensor from the laser pulse. First returns can be used to estimate canopy height in vegetated areas or rooftop height in developed areas, whereas last returns can be used to estimate the elevation of the land-surface elevation under vegetation.

To retain only last returns that indicate the ground elevation under vegetation, the data are filtered in ALPS. For bare-earth processing, the last-return data are filtered using an Iterative Random Consensus Filter (IRCF) in ALPS (Nayegandhi and others, 2009). A grid of non-overlapping square cells is superimposed on the original point cloud. An iterative process finds the largest number of points within a user-defined vertical tolerance to form an estimate of the ground elevation in each cell. The points within the vertical tolerance are selected as ground points. The ground points are then triangulated with a Delaunay's Triangulation (Shewchuck, 1996) to create a triangulated irregularnetwork (TIN) model. Points that were rejected by the IRCF can be examined again to see if they may be included in the bare-earth data. Each triangulated facet in the TIN model is defined as a threedimensional plane, which allows for consideration of steeply sloping ground. Any points that fall within the user-defined vertical range of the TIN are added as ground points. After a prescribed number of iterations, the points that are incorporated into the TIN are output as the bare-earth data.

To evaluate the accuracy of lidar data, a local topographic ground-based survey was conducted on September 24 and 25, 2006, for a small section of one of the northern Chandeleur Islands. During the survey, a local ground control-point network was established with the Global Positioning System (GPS) tied to a previously established National Geodetic Survey benchmark. Topographic mapping was conducted with a Spectra Precision Geodimeter 640 Total Station surveying instrument, which was tied to the established control-point network. The data were referenced to the North American (Horizontal) Datum of 1983 and the North American Vertical Datum of 1988 using the GEOID96 model reference frame, which was also used to process the lidar data. (More recent geoid models are available but using the GEOID96 model for both data sets introduces no error when the data are directly compared to each other.) The main species of vegetation at each of the 560 ground-survey points were identified, and vegetation heights were measured directly with a meter stick. At selected survey points, photos of the vegetation were taken to assist in comparison of lidar and ground-survey points.

\section{Analysis}

As described, first-return data can be used to estimate vegetation height, whereas last-return, or bare-earth, data can be used to estimate the ground elevation under vegetation. A comparison of firstreturn and bare-earth elevations was made by pairing each bare-earth data point in the survey area with the nearest first-return data point within a 1-m radius (fig. 2). The first-return and bare-earth elevations are highly correlated $(\rho=0.65)$, but bare-earth elevations are biased low when compared to first return (mean error $=-0.16 \mathrm{~m})$. The points where there is the greatest difference between first-return and bareearth elevations are most likely first returns from the top of tall vegetation and last returns from the ground under the vegetation. 


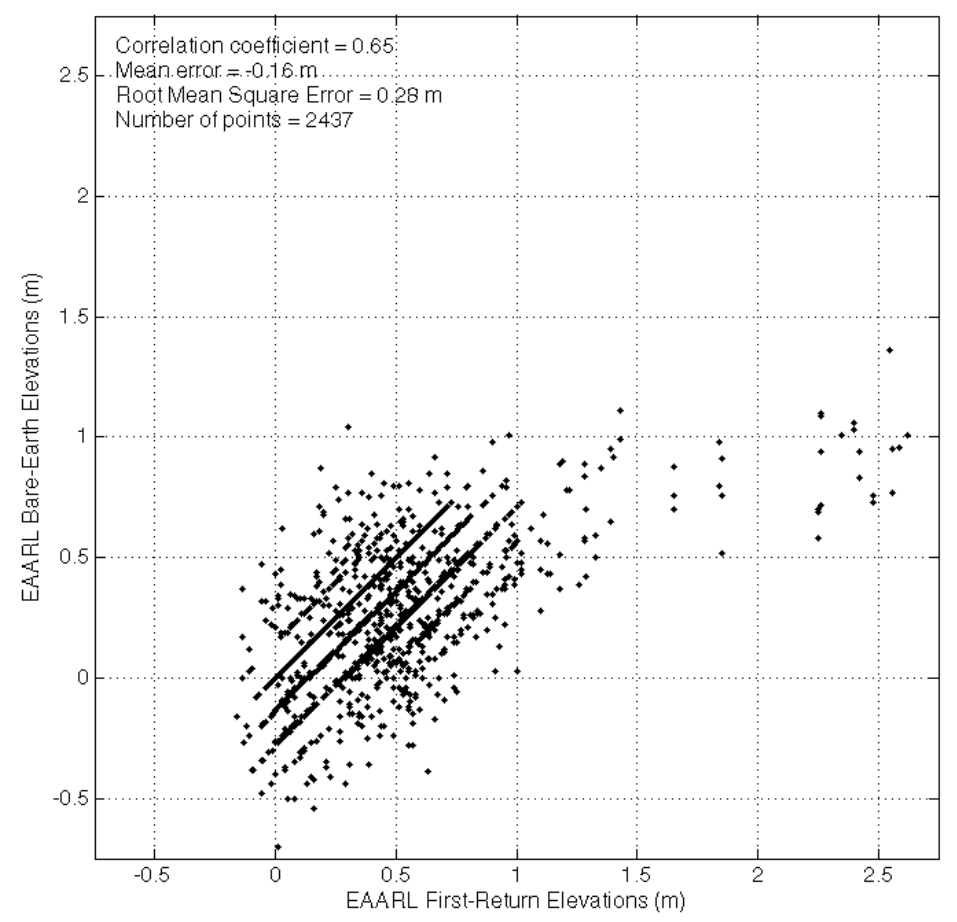

Figure 2. First-return lidar elevations compared to the nearest bare-earth elevations within the survey area.

To compare the ground-survey and lidar elevations, we averaged all lidar data points falling within a 2-m radius of the ground-survey point. An average value was computed for both bare-earth and first-return data, respectively. The bare-earth average elevations were then compared with the ground survey elevations, and the first-return average elevations were compared with the ground-survey elevations plus the measured vegetation height. For the comparisons, we assumed that the groundsurvey points and measured vegetation heights had no vertical errors.

For each comparison, the correlation coefficient ( $\rho$ ), mean error (ME), and root mean-square error (RMSE) were computed. The mean error indicates any bias in the lidar elevations, while the RMSE indicates the size of a typical deviation from the ground-based elevations. The bare-earth averaged lidar elevation and ground elevation have a correlation coefficient of 0.76 , revealing a high degree of linearity (fig. 3). The points are scattered about the 1-to-1 line, and the mean error is $-0.08 \mathrm{~m}$, indicating no detectable bias between the bare-earth lidar elevations and the ground-survey elevations. The RMS error for the comparison is $0.14 \mathrm{~m}$, well within the expected instrumental random error of 0.10 to $0.20 \mathrm{~m}$ (Nayegandhi and others, 2009).

The comparison of averaged first-return lidar elevations and ground elevations plus vegetation height yields different results (fig. 4). The correlation coefficient is 0.86 , higher than the correlation for the bare-earth comparison, but the lidar first-return elevations are lower than the ground plus vegetation heights $(\mathrm{ME}=-0.37 \mathrm{~m})$, indicating a bias. The RMS error is $0.47 \mathrm{~m}$, much larger than the expected random error of 0.10 to $0.20 \mathrm{~m}$ (Nayegandhi and others, 2009). These larger errors are typical of lidar first returns in short, sparse vegetation. In forested areas the first return reflects off the tree canopy, but in areas like the Chandeleur Islands where the vegetation is low and sparse, the first return is a mixture of returns from the top of the vegetation and the ground. 


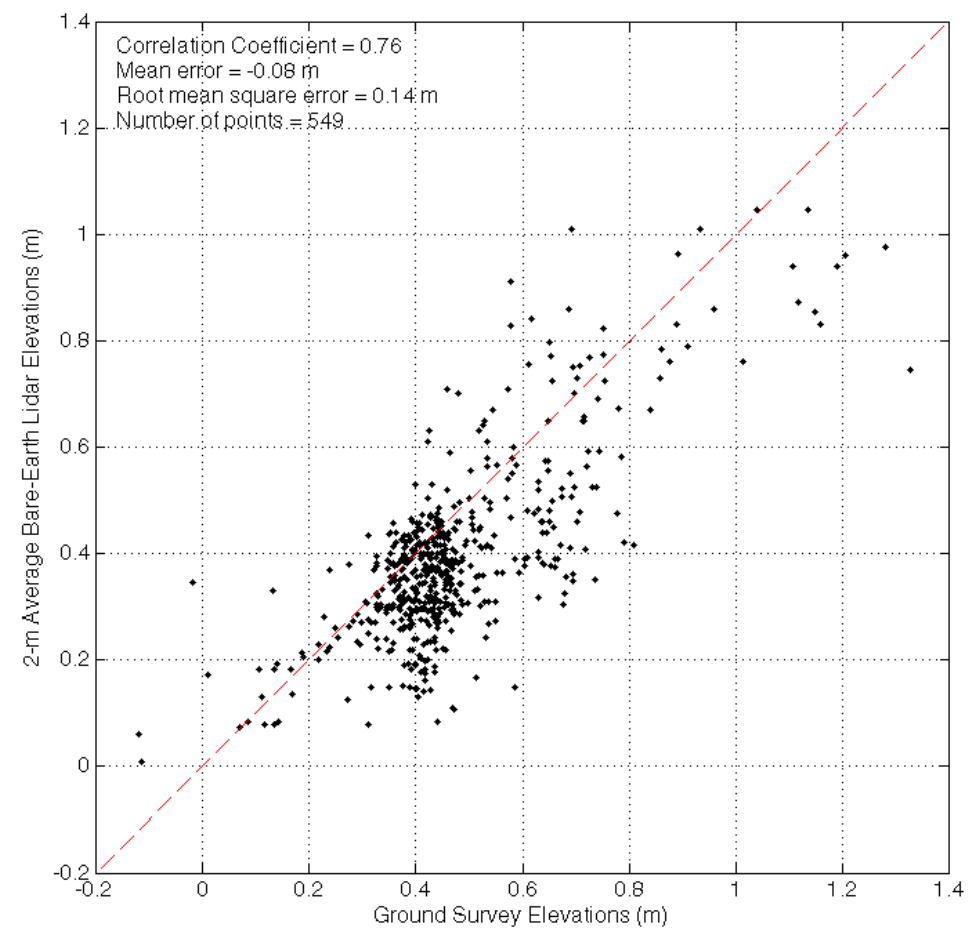

Figure 3. Bare-earth average lidar elevations compared to ground-survey elevations.

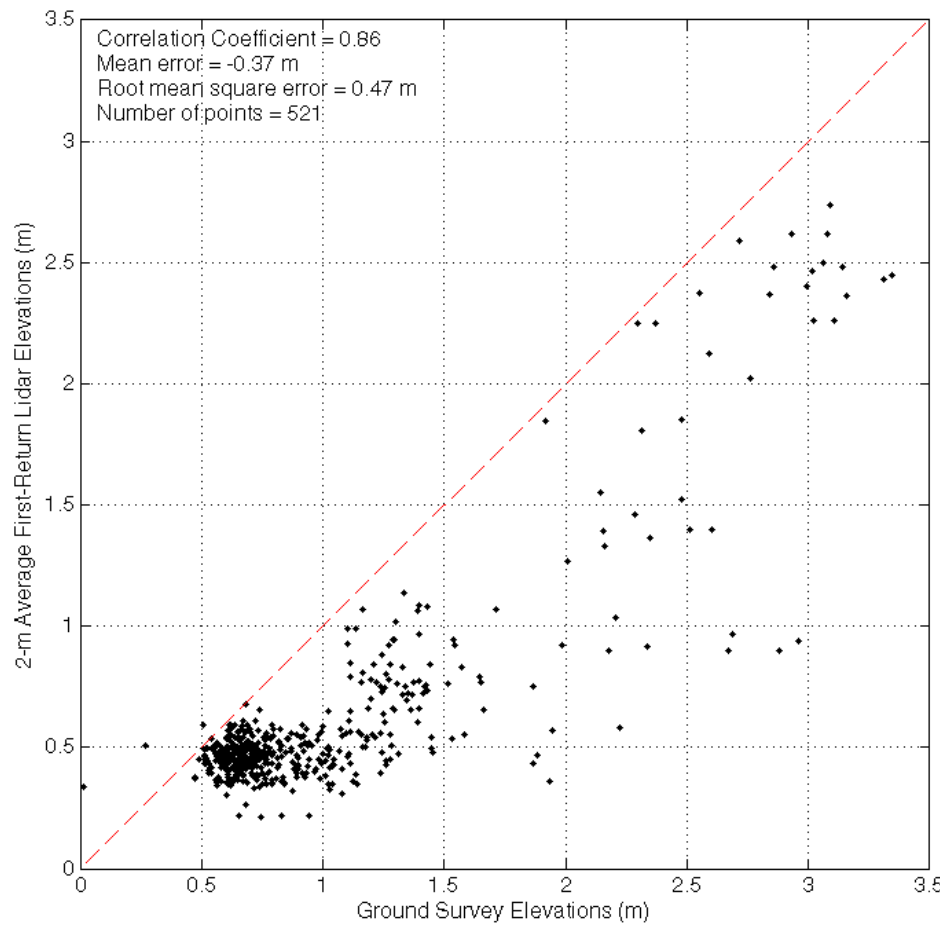

Figure 4. First-return average lidar elevations compared to ground plus vegetation height survey elevations. 
To test the ability of EAARL to accurately estimate vegetation heights and elevation under various types of vegetation, we divided the surveyed area into four main types of vegetation: short grasses (a mixture of Spartina alterniflora, Distichlis, and Salicornia, fig. 5A), typically 0.10 to $0.5 \mathrm{~m}$ high, black mangroves (Avicennia germinans, fig. 5A), typically 0.25 to $1.5 \mathrm{~m}$ high, patches of Spartina patens grass (fig. 5B), typically 0.5 to $1 \mathrm{~m}$ high, and Phragmites australis reed (fig. 5C), typically 1.5 to $2.5 \mathrm{~m}$ high. Then the bare-earth average elevations under each type of vegetation were compared to the ground-survey elevations, and the average first-return elevations were compared to the height of each vegetation type plus the ground-survey elevation.

The results of this analysis are shown in figures 6 and 7 . The small RMS (0.11 to $0.21 \mathrm{~m})$ and mean errors ( 0.02 to $0.17 \mathrm{~m}$ ) for bare-earth elevations (fig. 6) indicate the capability of the EAARL sensor combined with the ALPS bare-earth filtering to obtain an accurate measurement of the ground under various types of marsh and beach vegetation. The mean error $(0.24$ to $0.71 \mathrm{~m})$ and RMS error $(0.30$ to $0.88 \mathrm{~m})$ for the first-return comparison (fig. 7) are larger than the typical instrumental random error $(0.10$ to $0.20 \mathrm{~m})$. As expected, the RMS and mean errors increase with increasing vegetation height because lidar returns are a mix of reflections from the canopy top, ground, and everything in between.

\section{Conclusions}

After comparison of the EAARL first-return and bare-earth lidar elevations with a ground-based survey, we find that the EAARL sensor combined with the ALPS bare-earth filtering successfully estimated the elevation of the ground under various types of marsh and beach vegetation. For beach and marsh vegetation such as is found in the Chandeleurs, the EAARL first-return elevations are not indicative of vegetation height but rather a mixture of returns from vegetation and land. A similar study is planned to further evaluate the ability of EAARL to accurately measure vegetation height and ground elevation under beach vegetation at Cape Canaveral, Florida.

\section{Acknowledgements}

The USGS National Assessment of Coastal Change Hazards Project thanks the EAARL research team (Wayne Wright and Richard Mitchell) and ground surveyors (B.J. Reynolds and Nancy DeWitt). Colleagues in the St. Petersburg office helped with data collection (Dennis Krohn, Karen Morgan), processing and analysis (Charlene Sullivan, Peter Howd, and Mark Hansen). 

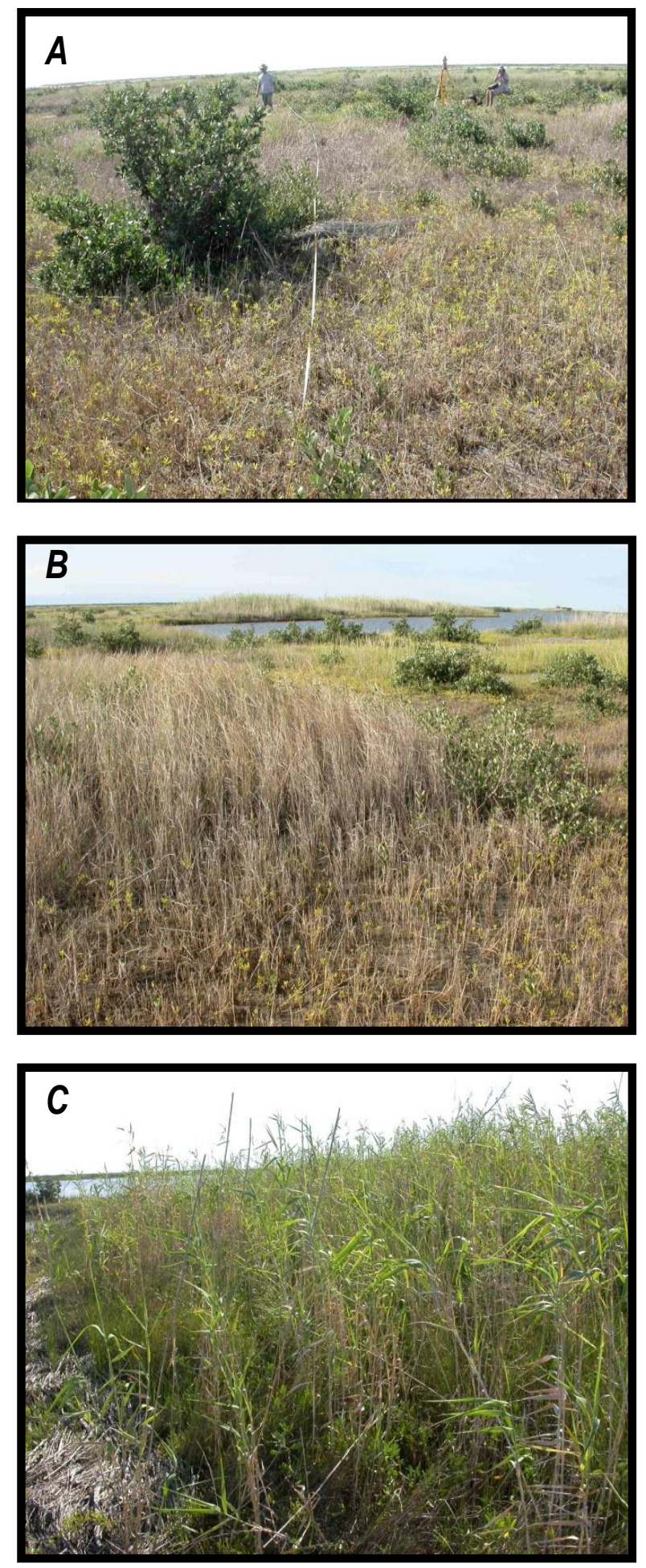

Figure 5. Photographs taken of the survey area showing vegetation types: $(A)$ black mangroves (Avicennia germinans, $0.4 \mathrm{~m}$ height) and short grasses (Spartina alterniflora, Distichlis, and Salicornia, $0.3 \mathrm{~m}),(B)$ saltmeadow cordgrass (Spartina patens, $0.7 \mathrm{~m}$ ), and $(C)$ common reed (Phragmites australis, $1.7 \mathrm{~m}$ ). 
Short Grasses
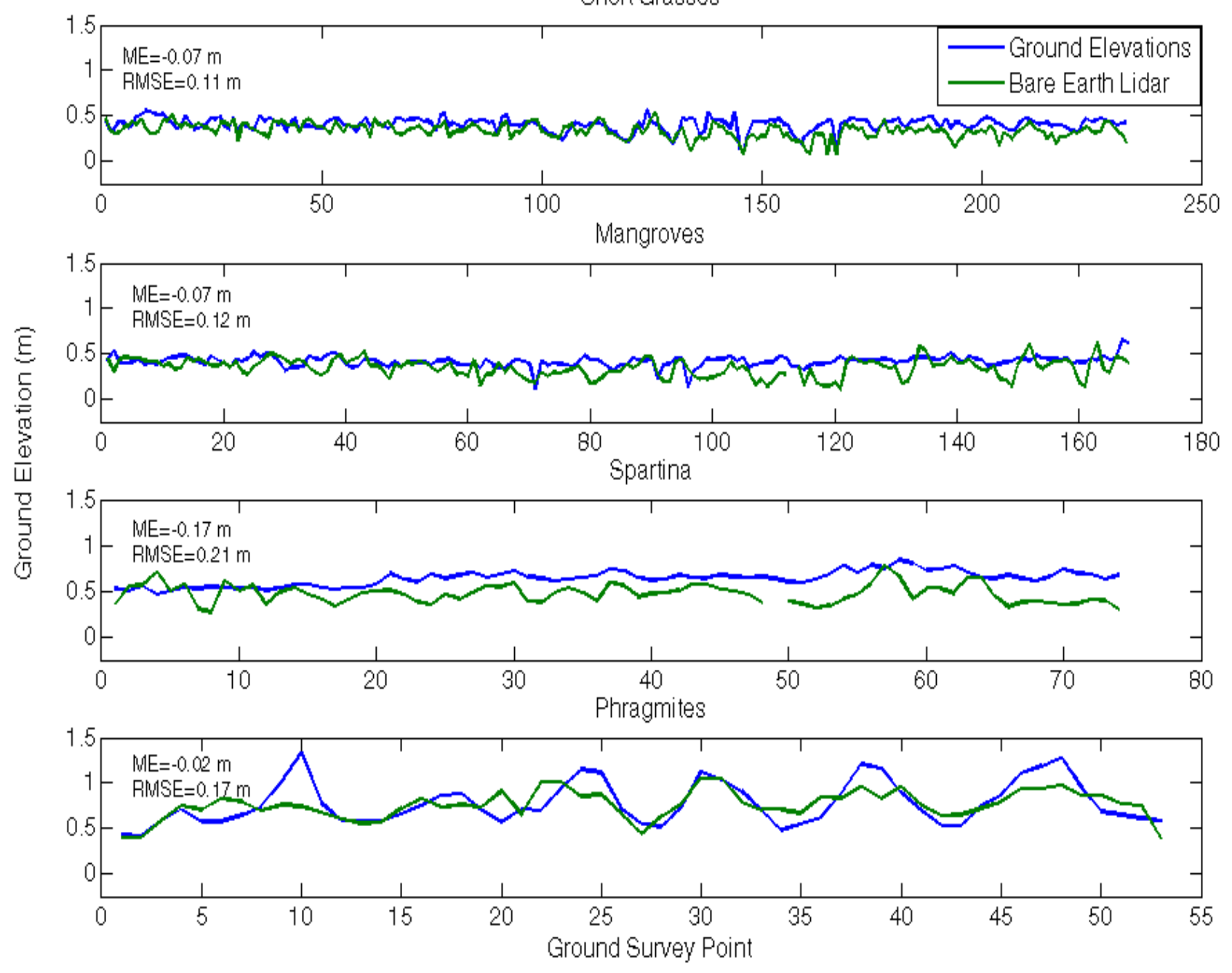

Figure 6. Average bare-earth (green) and ground-survey elevations (blue). There is no significant difference in the mean error (ME) or RMS (RMSE) error for the four different types of vegetation. 
Short Grasses
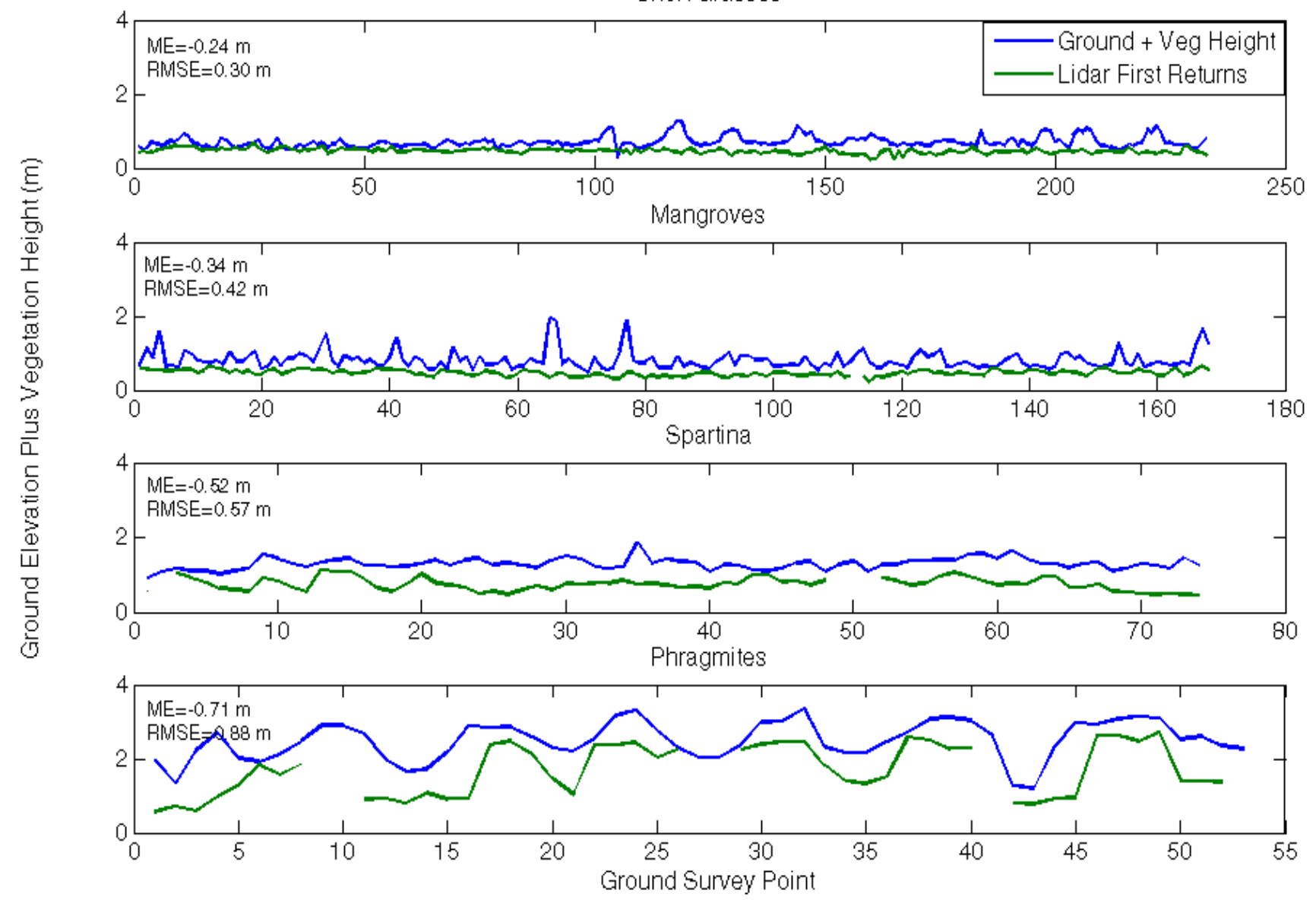

Figure 7. Average first-return elevations (green) and ground-survey elevation plus vegetation heights (blue). The mean error (ME) and RMS (RMSE) error are larger than the typical lidar random error and increase with vegetation height.

\section{References Cited}

Nayegandhi, Amar, Brock, J.C., Wright, C.W., and O'Connell, M.J., 2006, Evaluating a small footprint, waveform-resolving lidar over coastal vegetation communities: Photogrammetric Engineering \& Remote Sensing, v. 72, no. 12, p. 1407-1417.

Nayegandhi, Amar, Brock, J.C., and Wright, C.W., 2009, Small-footprint, waveform-resolving lidar estimation of submerged and sub-canopy topography in coastal environments: International Journal of Remote Sensing, v. 30, no. 4, p. 861-878.

Sallenger, Asbury, Wright, Wayne, Lillycrop, Jeff, Howd, Peter, Stockdon, Hilary, Guy, Kristy and Morgan, Karen, 2007, Extreme changes to barrier islands along the central Gulf of Mexico coast during Hurricane Katrina, in Farris, G.S., Smith, G.J., Crane, M.P., Demas, C.R., Robbins, L.L., and Lavoie, D.L., eds., Science and the storms: the USGS response to the hurricanes of 2005: U.S. Geological Survey Circular 1306, p. 113-118.

Shewchuck, J.R., 1996, Triangle: Engineering a 2D quality mesh generator and Delaunay triangulator, in Lin, M.C., and Manocha, D. eds., Applied computation geometry: towards geometric engineering: v. 1148 of Lecture Notes in Computer Science, Berlin, Springer-Verlag, p. 203-222. 